\title{
Attributes of Marital Love according to Church Documents
}

In the European context a long lasting love and the prosperity of couple were the main reasons for forming a marriage. The biological, psychical and cultural differences between male and female roles were taken for granted, but since the second half of 20th century, a different understanding of a marital couple and their roles came to the fore. The main aims and interests of marriage started to be separated from the 'emotional logic'. The marital relationship now comes in the first place; the other objectives are managed according to the demands of personal happiness. Contemporary men and women want to find their fulfilment also as a couple, often concentrating upon their individual happiness in the relationship with the necessary flexibility to adjust to new emerging circumstances. Personal happiness is more important than the success of the marital couple or of the family. ${ }^{1}$ More and more often, a marital relationship is based on love understood as an emotional satisfaction, but not as the mutual gift of two persons. In

1 Cf. H. Lombaerts, E. Osewska, Family and Family Catechesis in Europe Today. A Matter of Diversification, "Acta Paedagogica Vilnensia" 20 (2008), pp. 225-243; J. Stala, $W$ kierunku integralnej edukacji religijnej $w$ rodzinie. Próba refleksji nad nauczaniem Jana Pawła II w kontekście polskich uwarunkowań, Tarnów 2010. 
postmodern society the priority is given to sentimental love or falling in love. Everyone wants to be loved by the particular person in a special way, being all the time accepted, affirmed and adored whilst at the same time avoiding basic questions and processes of growth into maturity. The list of problems could be even longer, but one must also not overlook the encouraging opportunities that contemporary men and women face. In the last years, many Church and social associations, and movements have arisen to support young couples in their marital and family life. Taking into consideration the negative and positive attitudes towards marital love this article examines the significance and attributes of marital love in the light of Church documents.

\section{Love as a complete affirmation of a person}

In Europe, especially in the Western part of Europe, the image of the human person is focused more upon the individual than the communal. Modernity and postmodernity have developed an extensive philosophical and social justification and legitimation of this understanding of the human being. Considering the impact of individualism upon the understanding of love and the person, the following aspects are valued in order to achieve the aims proper to this individualistic image of the human person: autonomy, uniqueness, originality, the right of privacy, independence, success in achievements due to talents and creativity. The emphasis is put upon individual achievementsin the domain of 'havingmore than of being'. Regarding this phenomenon in light of the Bible, philosophy and the documents of Vatican Council II, John Paul II has been reminding that: "If therefore our time, the time of our generation... shows itself a time of great progress, it is also seen as a time of threat in many forms for man. ...The essential meaning of this 'kingship' and 'dominion' of man over the visible world, which the Creator himself gave man for his task, consists in the priority of ethics over technology, in the primacy of the person over things, and in the superiority of spirit over matter... What is in question is the advancement of persons, not just the multiplying of things that people can use. It is a matter-as a contemporary philosopher has said and as the Council has stated-not so much of 'having more' as of 'being more'. Indeed 
there is already a real perceptible danger that, while man's dominion over the world of things is making enormous advances, he should lose the essential threads of his dominion and in various ways let his humanity be subjected to the world and become himself something subject to manipulation in many ways-even if the manipulation is often not perceptible directly-through the whole of the organization of community life, through the production system and through pressure from the means of social communication. Man cannot relinquish himself or the place in the visible world that belongs to him; he cannot become the slave of things, the slave of economic systems, the slave of production, the slave of his own products.". This is essential to the question of the human's love and subsequently, also to the question of dignity. The human's dignity is strongly connected with love, and may be measured by the depth of love. "Only a person can love and only a person can be loved. This statement is primarily ontological in nature, and it gives rise to an ethical affirmation. Love is an ontological and ethical requirement of the person. The person must be loved, since love alone corresponds to what the person is. This explains the commandment of love, known already in the Old Testament (cf. Deut 6:5; Lev 19:18) and placed by Christ at the very centre of the Gospel ethos(cf. Mt 22:36-40; Mk 12:28-34). This also explains the primacy of love expressed by Saint Paul in the First Letter to the Corinthians: 'the greatest of these is love'(cf. 13:13)".3 This truth still need to be recalled, because it is of great importance for every human being, for the society, the state and the Church. Therefore, all those who dedicate their studies to offer a better understanding of human being should never lose sight of the meaning of human dignity and love.

The starting point to gain insight into the meaning of marital love is the issue of human dignity. In love, the affirmation of the other person, without acknowledging their dignity, is not possible. ${ }^{4}$ The human person - belonging to oneself and reigning over oneself is, above all, capable of giving the other person and, at the same time, being received as a gift ${ }^{5}$. The giving the other person oneself is appropriate to the human being nature and dignity. Only

\footnotetext{
Redemptor Hominis 16. Mulieris Dignitatem 29.

Cf. Jan Paweł II, Mężczyzną i niewiastą stworzył ich, vol. I, Lublin 1993, p. 373.

Cf. K. Wojtyła, Rodzina jako communio personarum, „Ateneum Kapłańskie” 83 (1978), p. 349; Jan Paweł II, Człowiek jest obrazem Boga (audiencja generalna 6 XII 1978), in: Nauczanie papieskie, vol. I, 1978, Poznań-Warszawa 1987, pp. 129-130.
} 
reciprocal and gradual self-giving enlivens and deepens the marital love, becoming a new source of offering oneself as a gift. This grows in accordance with its intrinsic regularity, by which it develops proportionately to the extent that this gift is received. ${ }^{6}$ More importantly, the giver and taker are on the same plane since, by mutually giving each other trust and respect for the freedom of choice, they are able to overcome even their most significant limitations. ${ }^{7}$

In presenting the whole picture of human love one cannot forget that the human being is called to love in his bodily and spiritual unity. Manhood and womanhood are complementary gifts and therefore, human sexuality is an element which integrates the ability to love. Sexuality is a fundamental factor of one's personality, one of the ways of one's existence, revelation, communication with others, feeling, expressing and experiencing human love. Thus, human sexuality is not solely a purely biological phenomenon, but, it rather concerns the inner essence of the human person per se. It is realized in a truly human fashion only when it constitutes an integral part of love in which man and woman are bound until death does them part. The absolute gift of bodies would be false if it weren't a sign and fruit of unmitigated personal self-giving through which the entire person is present, also in its worldly dimension. ${ }^{8}$ As it has been stressed by Paul VI, conjugal love may be considered a full affirmation only if it is a human, total, faithful, exclusive and fecund love. ${ }^{9}$ It is, thus, worth presenting these attributes successively. "This love is, above all, fully human, a compound of sense and spirit. It is not, then, merely a question of natural instinct or emotional drive. It is also, and above all, an act of the free will, whose trust is such that it is meant not only to survive the joys and sorrows of daily life, but also to grow, so that husband and wife become in a way one heart and one soul, and together attain their human fulfilment." ${ }^{10}$ Particularly in the context of the contemporary world, guided towards humanism, this personalist account of man is essential in the conveyance of the ultimate truth on conjugal and family love.

\footnotetext{
6 Cf. Jan Paweł II, Mężczyzna i niewiastą stworzył ich, Watykan 1986, p. 58.

Cf. Familiaris Consortio 26.

Cf. Familiaris Consortio 11.

Cf. Humanae Vitae 9; A. Sarmiento, Małżeństwo chrześcijańskie. Podręcznik teologii małżeństwa i rodziny, Kraków 2002, pp. 35-40.

10 Humanae Vitae 9.
} 
One ought to be reminded that a Christian's body is also part of his or her dignity. A marriage which is founded on the opening of "I" to "you" has become a privileged place where a man and a woman recognize each other as persons, establish a dialogue of love, as well as complement each other in the context of their entire life. In this situation, the choice of a partner does not depend on the social aspects or economic determinants, but rather, to a greater degree, on the personal maturity of a human. On the natural plane, love between man and woman is endowed with the greatest value. Man is not a pure spirit, therefore, he needs to express himself also on the physical level through a sign, gesture, smile, look. A sexual act externalizes the internal spiritual unity. ${ }^{11}$ In this total love husband and wife mutually give everything they have to one another in every situation in order to enrich themselves.

"Married love is also faithful and exclusive of all other, and this until death. This is how husband and wife understood it on the day on which, fully aware of what they were doing, they freely vowed themselves to one another in marriage. Though this fidelity of husband and wife sometimes presents difficulties, no one has the right to assert that it is impossible; it is, on the contrary, always honorable and meritorious. The example of countless married couples proves not only that fidelity is in accord with the nature of marriage, but also that it is the source of profound and enduring happiness." ${ }^{2}$ Faithfulness to one another means also fidelity to God's call and readiness to be open to serve, to forgive and support in every marital situation. "Married people must be distinguished for fidelity to their vocation, as is demanded by the indissoluble nature of the sacramental institution of marriage."13

According to Pope Paul VI, marital love is always fecund, because the loving interchange of husband and wife may easily become egocentric without opening up to new life. Marital love is, by its nature, dedicated to procreation. The strong, interpersonal relationship between husband and wife can strengthen, when they unite in the marital act and cooperating with God give a new life to a new human being. Along with the opening to accepting a child, eveno opening to supporte child's growth, education and

\footnotetext{
11 Cf. Amoris Laetitia 164.

12 Humanae Vitae 9

13 Redemptor Hominis 21.
} 
faith formation is needed. ${ }^{14}$ This is preciously why the Church constantly teaches that: "The two dimensions of conjugal union, the unitive and the procreative, cannot be artificially separated without damaging the deepest truth of the conjugal act itself." ${ }^{\prime 5}$

\section{Demandsset by marital love}

One of the fundamental tenets of love is that it is an act of will to love a person with an exclusive and faithful love. Man unceasingly needs this acceptance for his normal life and development. For this reason alone, during the betrothal, and later, marriage, there must be a decision of acceptance of the entire human person. Only this stance may constitute a foundation for an authentic, faithful and lasting marriage. There are three elements within the love between persons of the opposite sex: sexual union eros and caritas. ${ }^{16}$ The aspect of the Christian spousal love which needs to be emphasized is the fact of giving, which is not limited only to acceptance, a human way of giving. Christian love is participating in acceptance, in giving God through offering oneself. Man is capable of higher love: not only of a love of desire. This is a love of generosity, in the likeness of Divine love, which wishes and wants the good of another man since he is deemed worthy of being loved. "The love which is 'patient' and 'kind', and 'endures all things' (1 Cor 13:4,7) - is certainly a demanding love. But this is precisely the source of its beauty: by the very fact that it is demanding, it builds up the true good of man and allows it to radiate to others. The good, says Saint Thomas, is by its nature 'diffusive'. Love is true when it creates the good of persons and of communities; it creates that good and gives it to others. Only the one who is able to be demanding with himself in the name of love can also demand love from others. Love is demanding. It makes demands in all human situations; it is even more demanding in the case of those who are open to the Gospel.

14 Redemptor Hominis 21; J. Stala, Katecheza rodzinna w nauczaniu Kościoła od Soboru Watykańskiego II, Tarnów 2009; J. Stala, E. Osewska, Anders erziehen in Polen. Der Erziehungs- und Bildungsbegriff im Kontext eines sich ständig verändernden Europas des XXI. Jahrhunderts, Tarnów 2009; J. Stala, W kierunku integralnej edukacji religijnej w rodzinie. Próba refleksji nad nauczaniem Jana Pawła II w kontekście polskich uwarunkowań, Tarnów 2010.

15 Gratissimam Sane 12.

16 Cf. M. Ryś, Psychologia małżeństwa, Otwock 1997, p. 34. 
Is this not what Christ proclaims in 'his' commandment? Nowadays people need to rediscover this demanding love, for it is the truly firm foundation of the family, a foundation able to 'endure all things'. According to the Apostle, love is not able to 'endure all things' if it yields to 'jealousies', or if it is 'boastful... arrogant or rude' (cf. 1 Cor 13:5-6). True love, Saint Paul teaches, is different: 'Love believes all things, hopes all things, endures all things' (1 Cor 13:7). This is the very love which 'endures all things'. At work within it is the power and strength of God himself, who 'is love' ( 1 Jn 4:8,16). At work within it is also the power and strength of Christ, the Redeemer of man and Saviour of the world." ${ }^{17}$ The hymn to love expresses the truth about human love and sets very high demands on marital love. It is not easy to be patient, kind andaccepting in the various situations of everyday marital and family life. That is why the husband and wife need the special support coming from the strength of Jesus Christ.

The love which man experiences in the conjugal relation is based on the assumption of total acceptance of an individual with all of his abilities or limitations, as well as on the mutual support of family members in their personal development. Love, in the deepest sense, requires a person to perceive another person and his good, as well as to go beyond one's own egoism. It is of particular importance in the dialogue that is established between persons of the opposite sex. This dialogue, very difficult and delicate by its nature, necessitates increased responsibility for oneself. Through the act of love, the human being discovers a person (who has not yet been distinguished in the world of other persons) as unique, a person on a higher level of existence and value. ${ }^{18}$ "Continuing this line of thought, we also come upon the antithesis between individualism and personalism. Love, the civilization of love, is bound up with personalism. Why with personalism? And why does individualism threaten the civilization of love? We find a key to answering this in the Council's expression, a 'sincere gift'. Individualism presupposes the use of freedom whereby the subject does what he wants, in which he himself is the one to 'establish the truth' of whatever he finds pleasing or useful. He does not tolerate the fact that someone else 'wants' or

\footnotetext{
$17 \quad$ Gratissimam Sane 14.

18 Cf. Familiaris Consortio 22; K. Wrońska, Karola Wojtyty personalistyczna filozofia wychowania, in: Wychowanie na rozdrożu, ed. F. Adamski, Kraków 1999, p. 192; J. Majka, Wychowanie personalistyczne - wychowaniem integralnym, in: Człowiek - wychowanie - kultura, ed. F. Adamski, Kraków 1993, p. 98.
} 
demands something from him in the name of an objective truth. He does not want to "give" to another on the basis of truth; he does not want to become a 'sincere gift'. Individualism thus remains egocentric and selfish. The real antithesis between individualism and personalism emerges not only on the level of theory, but even more on that of ethos. The 'ethos' of personalism is altruistic: it moves the person to become a gift for others and to discover joy in giving himself. This is the joy about which Christ speaks (cf. Jn 15:11; $16: 20,22)$. What is needed then is for human societies, and the families who live within them, often in a context of struggle between the civilization of love and its opposites, to seek their solid foundation in a correct vision of man and of everything which determines the full 'realization' of his humanity. Opposed to the civilization of love is certainly the phenomenon of so-called 'free love'; this is particularly dangerous because it is usually suggested as a way of following one's 'real' feelings, but it is in fact destructive of love. How many families have been ruined because of 'free love'! To follow in every instance a 'real' emotional impulse by invoking a love 'liberated' from all conditionings, means nothing more than to make the individual a slave to those human instincts which Saint Thomas calls 'passions of the soul'. 'Free love' exploits human weaknesses; it gives them a certain 'venee' of respectability with the help of seduction and the blessing of public opinion. In this way, there is an attempt to 'sooth' consciences by creating a 'moral alibi. But not all the consequences are taken into consideration, especially when the ones who end up paying are, apart from the other spouse, the children, deprived of a father or mother and condemned to be in fact orphans of living parents." ${ }^{\prime 19}$ When the concept of free love is often presented by mass-media and accepted by society, and quickly links with many forms of human weakness, it soon becomes a permanent threat to marriage and the family, dramatically changing the perception of love. But is also necessary to remember that the strong love of spouses has the capacity to cure various kinds of wounds and it is strongly connected with forgiveness, reconciliation and spiritual depth..$^{20}$ When analysing the attributes of marital love one can see that consequently every Christian husband and wife who loves one another needs to recognize, understand, accept and follow the demanding standards of love.

\footnotetext{
19 Gratissimam Sane 14.

20 Cf. Gratissimam Sane 14.
} 


\section{Fidelity, indissolubility, uniqueness and exclusivity of conjugal love}

In the documents of the Second Vatican Council, the role of marital love as a foundation for fidelity and the indissoluble unity was underlined: "as a mutual gift of two persons, this intimate union and the good of the children impose total fidelity on the spouses and argue for an unbreakable oneness between them." 21 The same thesis has been often repeated by Pope John Paul II, who reminded that the fidelity and indissolubility of marriage comes directly from the very essence of love as a gift of one human being to another one. ${ }^{22}$

Indeed, marital faithfulness is a result of a total acceptance of a person who gives oneself. Similarly, unity and inseparability merge in marriage into reciprocal giving and accepting each other by spouses. Since a person is of the greatest value in the natural order, he or she must always be treated as a goal, not a means for achieving another goal. Thus, when two persons make a decision to be joined in the holy matrimony of love and union of life, then, this choice, manifested in the matrimonial consent, creates a new ontic reality that constitutes a foundation for the irrevocable character of this relationship. ${ }^{23}$ Marriage is a special communion of persons which must be based on love, which is unique and exclusive. ${ }^{24}$ The conjugal communion of love ought to be characterized not only by unity but also by its inseparability and mutual fidelity of spouses. Pope Benedict XVI indicates that "eros directs man towards marriage, to a bond which is unique and definitive; thus, and only thus, does it fulfil its deepest purpose. Corresponding to the image of a monotheistic God is monogamous marriage. Marriage based on exclusive and definitive love becomes the icon of the relationship between God and his people and vice versa. God's way of loving becomes the measure of human love. This close connection between eros and marriage in the Bible has practically no equivalent in extra-biblical literature." ${ }^{25}$

\footnotetext{
21 Cf. Gaudium et Spes 48; Cf. Gaudium et Spes 49.

22 Cf. Gratissimam Sane 11; Familiaris Consortio 13; Familiaris Consortio 20.

23 Cf. C. Rychlicki, Sakramentalny charakter przymierza małżńskiego, Płock 1997, p. 342 .

24 Cf. Gratissimam Sane 10.

25 Deus Caritas Est 11.
} 
In the perspective of the New Testament, the Church reminds Catholics of the truth of conjugal love, which is founded on Jesus Christ. ${ }^{26}$ Marriage is a symbol of the relationship between Jesus Christ and the Church, attained at the price of His death, whose most significant element is love. This love is a foundation of the unity and inseparability of marriage; if it were temporary, it could not be the symbol of the relationship of Jesus Christ with the Church. Therefore, a Christian marriage must be indissoluble and last till the end of life. ${ }^{27}$ True marital love may develop only in a lasting, thus indissoluble, relationship. ${ }^{28}$ Love combines, in itself, what is human with what is divine. Only fidelity to God and fidelity to love may create a real harmony in the life of the spouses. It is for this reason that divorce is not permitted in the Catholic Church. In critical situations, marital separation is allowed, still, it does not grant the privilege to entere a second sacrament of matrimony with another person. Thus, the Church constantly reminds that: "In family life, we need to cultivate that strength of love which can help us fight every evil threatening it. Love does not yield to resentment, scorn for others or the desire to hurt or to gain some advantage. The Christian ideal, especially in families, is a love that never gives up." ${ }^{29}$

When, in the beginning of the $21^{\text {st }}$ Century a growing number of people admit a lack of interest in marriage, they do not necessarily lack interest in love and relationships. The so-called 'noninterest in marriage' diagnosis reveals rather that the demands of Christian marriage based on inseparability, fidelity, uniqueness and exclusivity of conjugal love is difficult to achieve and teaching of the Church's doctrine is no longer widely accepted. In reality, the 'reception' of the Roman Catholic Church's teaching leads to the construction of an independent, personal response, far from a submissive and passive one. Today's believers are more diversified and choosey and so the irresponses differ from the orthopraxis and standardised behavior.

\footnotetext{
26 Cf. Familiaris Consortio 20.

27 Cf. Familiaris Consortio 19.

28 Cf. K. Romaniuk, Małżeństwo i rodzina według Biblii, Warszawa 1994, pp. 11-20.

$29 \quad$ Amoris Laetitia 119.
} 


\section{Conjugal love as a communion of a woman and a man}

Since every human fully discovers and confirms his own identity through love, an obvious conclusion may thus be drawn that the conjugal and family communion truly deserves the name of communio personarum. ${ }^{30}$ However, in order for that to happen, family life must bear the experience of communion and participation. For this reason, spouses receive a grace, but also a serious responsibility, to build the true communion of persons on the day-to-day basis. "The love between husband and wife and, in a derivatory and broader way, the love between members of the same family-between parents and children, brothers and sisters and relatives and members of the household-is given life and sustenance by an unceasing inner dynamism leading the family to ever deeper and more intense communion, which is the foundation and soul of the community of marriage and the family." ${ }^{31}$ The responsibility for building. the unity of the family rests on all family members, but, first and foremost, on the spouses through their mutual respect, love, everyday service and the openness to joy and sorrow. A very significant role in building family unity is played by the openness to the other person, wishing for and realizing the common good, overcoming difficulties and searching for solutions together. It should also be borne in mind that eliminating conflicts and discords, willingness for reconciliation, are always a testimony for obedience to God, who encourages people to unity. ${ }^{32}$ Nevertheless, true unity comes into being only when each person, individually, remains who they are, and nobody loses oneself, the true self. What is more, thanks to the other person, he or she becomes somebody complete only for others. The conjugal community possesses sufficient strength to give persons belonging to it, a place where they will find their own identity. At the same time, each member of the family should show concern, not only for his or her own life but for lives of other members of the family, their needs, hopes and ideals. ${ }^{33}$

The foundation of the communion is the covenant in which man and woman, conscious of the dynamism attributed to the human person,

\footnotetext{
30 Cf. Redemptor Hominis 10; Familiaris Consortio 18.

31 Familiaris Consortio 18.

32 Cf. Familiaris Consortio 21; LF 9.

33 Cf. Familiaris Consortio 15; Familiaris Consortio 18; Familiaris Consortio 21.
} 
mutually give themselves to each other and accept each other. ${ }^{34}$ Despite the difficulties, they retain the good of indissolubility and, as a result, become a sign of fidelity to God and all people and bear witness to their faith and love. ${ }^{35}$ Love and truth open man to God, giving man the inspiration to live in the communion. Man and woman are predisposed to creating the bodily-spiritual "communion of persons", "one flesh", which corresponds with their personal dignity. The true covenant of marriage should be open to expanding into a broader community of the family, which may be accomplished through the procreation and education of children. ${ }^{36}$ The reciprocal gift of humanity, defined by the personally authentic character of the conjugal community, leads to parenthood through a fecund intercourse of husband and wife. Through each act of birth a new person is introduced to the primary conjugal community of persons. The essence of communiopersonarum is that motherhood necessarily implies fatherhood, andin turn, fatherhood necessarily implies motherhood. Parenthood, as a personalist value, actualizes itself solely through a reciprocal gift: spouses mutually bestow a gift of fatherhood and motherhood on each other in the act of a selfless gift as well as accepting this gift. ${ }^{37}$ For parents, the offspring becomes a gift which constitutes a response to their stance of grace manifested in the unconditional readiness to welcome a child from God's hands. Thus, a reality of communion is built also between parents and children, which reveals the true nature of the family. ${ }^{38}$

$$
\star * \star
$$

Conjugal love is a dynamic and multi-faceted reality since it is, at the same time, physical and spiritual, open to God and to the other person. It also requires giving oneself for the sake of the new 'we'. For this reason, the Catholic Church places a great emphasis on the correct understanding and realization of the love between Christian spouses, which is manifested in the delivered instructions as well as the documents. What lies at the foundation of the teaching of the consecutive popes: Paul VI, John Paul II, Benedict XVI

\footnotetext{
34 Cf. Humanae Vitae 9.

35 Cf. Familiaris Consortio 20.

36 Cf. Gratissimam Sane 7.

37 Cf. K. Wojtyła, Rodzicielstwo a communio personarum, „Ateneum Kapłańskie” 67 (1975) no. 396, pp. 18-19.

38 Cf. Familiaris Consortio 15.
} 
and Francis is the conviction that the affianced and spouses need to learn the true nature and dignity of love from the perspective of theology in order to better comprehend it, and, in turn, embrace it, undertake it and fulfil its demands in the daily life. Christian marriage, built on the foundation of love which is human, total, faithful, exclusive, fecund, originating in the love of God, as well as ennobled through the sacrament of matrimony, will endure through the current socio-cultural tendencies and will strengthen the society, nation and country.

\section{Bibliography}

Jan Paweł II, Człowiek jest obrazem Boga (audiencja generalna 6 XII 1978), in: Nauczanie papieskie, vol. I, 1978, Poznań-Warszawa 1987.

Jan Paweł II, Mężczyzna i niewiasta stworzył ich, Watykan 1986.

Lombaerts H., Osewska E., Family and Family Catechesis in Europe Today. A Matter of Diversification, "Acta Paedagogica Vilnensia” 20 (2008), pp. 225-243.

Majka J., Wychowanie personalistyczne - wychowaniem integralnym, in: Człowiek - wychowanie - kultura, ed. F. Adamski, Kraków 1993.

Romaniuk K., Małżenstwo i rodzina według Biblii, Warszawa 1994.

Rychlicki C., Sakramentalny charakter przymierza małżeńskiego, Płock 1997.

Ryś M., Psychologia małżeństwa, Otwock 1997.

Sarmiento A., Małżeństwo chrześcijańskie. Podręcznik teologii małżeństwa i rodziny, Kraków 2002.

Stala J., Katecheza rodzinna w nauczaniu Kościoła od Soboru Watykańskiego II, Tarnów 2009.

Stala J., Osewska E., Anders erziehen in Polen. Der Erziehungs- und Bildungsbegriff im Kontext eines sich ständig verändernden Europas des XXI. Jahrhunderts, Tarnów 2009.

Stala J., W kierunku integralnej edukacji religijnej $w$ rodzinie. Próba refleksji nad nauczaniem Jana Pawła II w kontekście polskich uwarunkowań, Tarnów 2010.

Wojtyła K., Rodzicielstwo a communio personarum, „Ateneum Kapłańskie” 67 (1975) no. 396, pp. 18-19.

Wrońska K., Karola Wojtyły personalistyczna filozofia wychowania, in: Wychowanie na rozdrożu, ed. F. Adamski, Kraków 1999. 
